\title{
Challenging absolute executive powers in times of corona: re-examining constitutional courts and the collective right to public contestation as instruments of institutional control
}

\author{
Jessika Eichler
}

Department of Law and Anthropology, Max Planck Institute for Social Anthropology, Halle, Germany and Center for International Studies (CERI), Sciences Po, Paris, France, and

Sumit Sonkar

Faculty of Law, The Chinese University of Hong Kong, Hong Kong, China

\begin{abstract}
Purpose - The CoViD-19 pandemic has brought about a panoply of institutional challenges both domestically and in the international arena. Classical constitutional theory thereby underwent a reinvention by the executive for the sake of speedy policy action and to the detriment of institutional control while favouring authoritarian forms of governance. This paper concerns itself with institutional responses to such developments, placing emphasis on the role of the judiciary and people*s in contesting emergency decrees and other executive orders, especially where fundamental rights are infringed upon. The paper aims to explore the difficulties arising with exerting absolute executive powers during the health crisis, the respective role assumed by constitutional courts and the impact of the new governance paradigm on forms of public contestation, also as a means of quasi institutional control.

Design/methodology/approach - Indeed, the right to health may be translated into political discourse and become foundational to security and public interest paradigms. This may result in a shrinking public space given the constraints to the freedom of movement. In the name of public safety, the (collective) right to assembly, expression and protest have been submitted to major limitations in that regard.

Findings - Ultimately, this re-opens debates on the meaning of absolute rights and contextualities of derogations, as well as the reconcilability of civil and political rights and economic, social and cultural rights. It also exposes social inequalities, social justice dimensions and vulnerabilities, often exacerbated by the health crisis; migrant rights demonstrably face particularly severe and intersectional forms of violations.

(C) Jessika Eichler and Sumit Sonkar. Published in Review of Economics and Political Science. Published by Emerald Publishing Limited. This article is published under the Creative Commons Attribution (CC BY 4.0) licence. Anyone may reproduce, distribute, translate and create derivative works of this article (for both commercial and non-commercial purposes), subject to full attribution to the original publication and authors. The full terms of this licence maybe seen at http://creativecommons.org/licences/by/4.0/legalcode

Fritz Thyssen Stiftung.

AZ.40.18.0.005EL.

The first author acknowledges the following financial support, a Fritz Thyssen post-doc grant (AZ.40.18.0.005EL) and support provided in the framework of the Alfred Grosser Chair*e 2019-2020 at Sciences Po (Fritz Thyssen Foundation and Sciences Po).
\end{abstract}

Received 31 August 2020 Revised 29 November 2020 Accepted 29 November 2020 
REPS

6,1

Originality/value - Particular values lie with the interdisciplinary approach embraced in this paper; the authors draw on a variety of social sciences disciplines to shed light on this very current issue. Both theoretical and empirical methods are used and combined here, making sense of the underlying logic of virus governance and its impacts on fundamental rights.

Keywords Corona virus, COVID19, Fundamental rights, Constitutional courts, Executive measures, Right to assembly and protest

Paper type Research paper

\section{Introduction}

The COVID-19 pandemic has given rise to new forms of health governance, hitherto unpreceded in contemporary history. While respective measures of confinement or other forms of quarantine permeate eras of pandemics, being attributable to totalitarian regimes (Tréguer, 2020; Bourdelais, 2014), the Corona pandemic is responded to by twentieth century constitutionalism, including supposedly controlled executive powers. Ebola as experienced by the Democratic Republic of Congo possibly resembles the global pandemic, which may become a political illness (Diallo, 2020). In this new globalised age, affected States have come to embrace "expert governance" or "technocratic governance" paradigms to handle public health crises while questions on accountability for technocrats' actions and omissions remain unresponded. In the French case, for instance, such governance has come to be institutionalised, by establishing a ministerial instance, the Scientific Council (CoViD19), to advice the government on virus-related measures; its government-prone position might, however, shine through official statements. In the UK context, a gradual approach was observed, resisting, for instance, its obligation to respond to public inquiry and scrutiny; it could be generally advanced that the failure to take expert advice into account could constitute a breach of the State's obligations (Bates, 2020). Such newly created instances could barely be considered truly autonomous, being largely void of decision-making capacities. In that sense, the success of measures is qualified by the extent to which "epistemic belief in scientific evidence" is shared by the political community and such expert scientific knowledge is truly independent of political influence (Lazarus, 2020a, 2020b).

Major institutional insecurities, however, surround executive orders, demonstrating high levels of arbitrariness and absoluteness. A detailed analysis of the defects and deficiencies of the social and political structure is, hence, required, finding its roots in recent history. This includes classical Montesquieuian debates on checks and balances, involving the executive and judicative in particular. In fact, constitution-making dating back to the Nineteenth and twentieth centuries actively confronted a common institutional malaise, the abuse of power (Montesquieu, 1892), one of the main deficiencies of the State we are arguably observing again today. Current forms of governance seemingly return to a state predominating political practice prior to the age of "balanced constitutionalism" (Montesquieu, 1892). That is attributing exclusive importance to a twofold division, including legislative and executive functions of governance (Vile, 1967; Locke, 1689), the latter entailing the function of law enforcement persisting until today. Others place emphasis on the power to coerce or le pouvoir coactif, demonstrating particular relevance in current CoViD19 governance (Pufendorf, 1672): penalising conduct has indeed been tested to its limits in times of sanitary emergency. A final resembling theoretical underpinning can be found in the doctrine of "mixed government", predominant in pre-Civil War 
England in the following way (Vile, 1967): on the one hand, the executive now circumvents the legislature and existing laws by establishing extraordinary orders of emergency to the detriment of "legislative supremacy", on the other hand, so-called agencies of governance received particular attention, materialising in today's executive, populist parties and their leaders (consider the governments in place in Hungary and Poland, to be discussed further).

We will, hence, explore the transforming role of CoViD19 governance in the first part, shedding light on the challenges related to authoritarianism and other forms of systemic dilemmas. Indeed, the pandemic needs to be understood in the context of "a precarious time of democratic backsliding and growing illiberalism", as well as "a global rise in autocratic populism”. Relatedly, we approach executive orders emitted by these regimes in detail in a second part, starting off from conceptual legalisms inherent to such newly invoked orders these may include "sanitary emergencies", "national interest" or "public emergencies". Departing from these technicalities, we explore the role played by constitutional courts as instruments of institutional control in the third part; these most notably critically engage with fundamental rights at stake here.

Indeed, a related systemic ill concerns the disproportionate impacts caused by such executive orders. As observed by UN Secretary General António Guterres, the virus "does not care about any distinction" (Guterres, 2020). It may not differentiate between any social, ethnic, cultural or religious boundaries, however, it certainly affects health care workers (The Lancet, 2020) while disproportionately affecting the otherwise disadvantaged people*s the most, encompassing gender (Titan Alon et al., 2020; Clare Wenham et al., 2020) or ethnic grounds, indigenous peoples (Ferrante and Fearnside, 2020), migrants, asylum seekers and prisoners (United Nations Office of the High Commissioner for Human Rights, 2020), people suffering dementia (Wang et al., 2020), disabled (Tidball, 2020), aged and other socio-economically marginalised people*s (HRW, 2020; Ryan, 2020). While impacts of social distancing may be diverse, ranging from limitations on family events and mass gatherings such as the Olympic Games (Ziad A Memish et al., 2020) to expressing opinion and dissent collectively in the public space, we place a focus on the latter. Given the absoluteness of executive orders, we understand public dissent as one way of controlling the executive, as a fourth instance of - albeit - informal control or "people*s' governance". In that sense, questions of legitimacy and representativity of executive governance come to the fore, allowing for some form of anti-Hobbsian legacy to be established (Hobbes, 1651): most notably, extraordinary levels of power are subsumed under the executive, pretending to represent a State's population without granting meaningful possibilities of control.

Conversely, current forms of representative democratic governance demand forums for public participation, commonly in the form of electoral rights and rights exercised in the public space. Reconciling the right to vote and health safety has proven challenging indeed: in the French case, CoViD19-related confinement was arguably strategically declared in the days following the first tour of State-wide municipal elections. Similar challenges were tackled by the Ghanaian and newly elected Slovakian governments, respectively, where State-wide elections had taken place. In the Polish case, elections had to be postponed as a consequence of the difficulties arising with the virus (Meyer-Resende, 2020). Major lessons may similarly be derived from African States where several elections processes would fall into the time of the pandemic: postponing the elections was ruled out based on security issues their institutions were facing, including violent repression of demonstrations in New Guinee or Jihadist threats in Mali (Diallo, 2020). It was further argued that such 
REPS

6,1

postponement would not only enhance political tensions, but affect the democratic functioning of the State (Diallo, 2020). Civic participation in public life may, however, find expression beyond election processes. We, hence, examine the effectiveness of the right to social protest and other forms of collective (public) expression in a fourth part, tracing its meaning evolving in current jurisprudential developments. Disproportionate impacts may be understood as intrinsic to and generally curtailing particular rights at stake. They could, however, also be attributed to specific groups of people, bringing about distinct forms of inequalities and vulnerabilities. In a final part, we thus, attempt to uncover the discriminate impact of such invisibilising executive orders by making sense of multiple, at times intersectional, grounds of discrimination and exclusion from enjoying fundamental rights and the right to collective public expression and dissent in particular.

\section{The transformative role of CoViD-19 governance: Authoritarianism and other systemic dilemmas}

The disastrous impact of measures adopted by the States to combat ongoing global public health crises may go beyond the economic realm and tip the scales of democracy in favour of authoritarianism (Daly, 2020). Following the Hobbsian model of governance, authoritarian political leaders across the world are exploiting the uncertainty inflicted by the pandemic to consolidate and expand their power over constitutional orders (Daragahi, 2020). This phenomenon can be gauged from the fact that more than 84 countries have already declared emergencies in their respective States, which may undermine civil rights and foundational values of a democratic order (Center for Civil and Political Rights, 2020). Indeed, such concentration of executive powers and the simultaneous severe restrictions on fundamental constitutional rights (Gargarella, 2020) are emblematic of the currently shifting role of the State and merits further analysis.

One problematic aspect of clamping down on nearly all movement and public activities is that such exercise of emergency powers may not be constitutionally permissible as many constitutions do not provide public health crises a specific ground for its declaration [1]. In the context of dangers of emergency powers, Jackson J. in his landmark dissenting opinion in Korematsu $v$ US [2] stated that it is "a loaded weapon ready for the hand of any authority that can bring forward a plausible claim of an urgent need". On the pretext of containing the pandemic, populist governments are, hence, tightening their control over democracies that may lead to colossal violation of rights and regressively change the contours of the local and global political order (Gebrekidan, 2020).

In fact, States may in fact be tempted to consolidate control over constitutional structures on future occasions based on such exceptional regimes. This ploy to consolidate power may probably become the pandemic's most lasting and enduring legacy (Roth, 2020). In that sense, as the trends suggest, States sliding into authoritarianism seems imminent (Gaspard, 2020). Moreover, the legitimisation of broad powers to governmental authorities during and beyond the pandemic generally catapults democratic processes while subjugating dissenting voices (Quraishi, 2020). Institutional control and accountability mechanisms thereby prove to become a necessary corollary: Rousseauian forms of people*s-steered governance may hence, add to the ordinary functioning of second chamber opposition, parliamentary opposition or judicial response mechanisms. In fact, CoViD-19 has come with a problem of democratic scrutiny and legal accountability (Lazarus, 2020b). Exceptions have been observed in the case of New Zealand where an ad hoc accountability mechanism ("Epidemic Response Committee") has been set-up to scrutinise executive action instead of ordinary procedures via Parliament (Lazarus, 2020a). 
Other ways of dissenting to executive rule may be sought through the internal set-up of the State. In times of emergency, most Constitutions allow the federal government to intervene in the provincial States' internal administration to ensure democratic stability (Bulmer, 2017). However, such measures may flare-up constitutional tensions between the federal and provincial governments (MacKell, 2020). To curb the spread of the COVID-19 pandemic, swift, decisive and local actions are critical to the protection of populations from homogenising decisions adopted by federal governance. In fact, the principle of proportionality may be best applied where local levels are taken into account (Lange, 2020). However, such unilateral measures may jeopardise the constitutional functioning of the State, especially as to federalism and other forms of exercising subsidiarity, which divides powers at different levels of government. It may be argued that the provincial State machinery is in fact at the forefront to combat the pandemic; accordingly, decision-making powers may need to be attributed to the former in the first place. As the Indian context demonstrates, the financial concentration of wealth in the central government since the adoption of the goods and services tax regime (Vaitheeswaran and Datar, 2015) has reduced provincial governments' capacity to respond effectively to the pandemic. Ergo, the Indian perspective of federalism, as stated in Kuldip Nayar v Union of India [3] may need to be revisited.

Conversely, responsibilities for the consequences of the emergency may be delegated from the Head of Government to federal governments and regional authorities as illustrated by the Russian Federation, being ultimately attributable to legal uncertainty around emergencies (Kalinichenko and Moskovkina, 2020). Reasons may, for instance, lie in the unclear separation of powers between federal and regional governments or what could be termed an intra-State dilemma of multi-level governance in times of Corona (Lange, 2020). Such criticism may, however, also be raised at general levels: the multiplicity of legal acts adopted across EU Member States and beyond led to a weakening of legal certainty, which became apparent in unclarity and incoherence in terms of competence to enact CoViD-19 measures and the question of legal basis (Meyer-Resende, 2020). Accountability may, however, also be strengthened inside executive powers: a form of "intra-executive accountability" may be demanded, illustrated by the "CoViD-19 judge" in South Africa that "operates within the executive structure" and as relating to enforcement of regulations (Friedman, 2020).

\section{Constructing and adopting regimes of judicial exceptionalism in times of corona: "sanitary emergencies" and beyond}

Executive rule has, however, gained the clearest shape when invoking judicial exceptionalism that is extraordinary regimes that would allow for derogations of specific rights while furnishing governments with almost absolute powers. Apart from dedicated legal regimes, pre-existing legal acts have been used, that is "ordinary powers to be extraordinary in their scope", applying ordinary legislation that was meant to be reserved for ultra vires action (Grogan, 2020). Such a course of action follows the principle of normalcy, namely, dealing with the pandemic by means of normally applicable powers and procedures while requiring human rights guarantees to be fulfilled (Scheinin, 2020). Extraordinary measures, however, should be impermanent and be controlled by means of scheduled democratic reviews (Lazarus, 2020a). Another safeguarding effect is established here, arguably paradoxically by means of official derogations under international human rights treaties. By declaring an emergency and notifying the respective body, emergency powers define the way such powers are exercised, including inter-alia the principles of "necessity, 
REPS

6,1

proportionality, exigency, temporality and a commitment to human rights as a framework for legitimate emergency measures" (Greene, 2020). The judiciary comes to play a crucial part in this by requiring sunset provisions to be put in place as demonstrated by courts reviewing departmental CoViD-19 legislation in Germany (Theil, 2020) or parliamentary review controlling time limits in South Africa (Friedman, 2020).

Most emblematic might show to be Hungarian context in fostering executive powers by means of Corona-specific measures. Most notably, Hungary's parliament passed legislation that gave Prime Minister Viktor Orban indefinite, extraordinary, sweeping and unlimited powers to tackle the pandemic, which, in turn, may undermine the constitutional rights of Hungarians (Serhan, 2020). Further institutional restrictions were introduced with the amended Health Act that would ignore constitutional safeguards and suspend the operation of all institutions, including arguably the judiciary and constitutional court (Halmai et al., 2020). Ordinary courts have been closed as part of CoViD19 policies, hence avoiding any review of proportionality principles in terms of measures enacted to prevent the spread of the virus (Grogan, 2020). Ultimately and essentially, new legislation would criminalise speech addressing the pandemic such as news distorting the truth (MeyerResende, 2020), constituting a severe intervention with individual and collective liberties. Criminalisation has arguably been used as a strategy both to silence criticism of the government and to frustrate media efforts to hold it accountable (Lazarus, 2020a).

While less far-reaching in nature, most States facing the pandemic have enacted executive decrees under and by creating special legal orders: this would range from sanitary emergencies to declaring the pandemic a war as demonstrated by the French and US contexts, respectively. Ambivalent legal terminology demonstrably enables such exceptions to find their way into restrictive decrees, prime ministerial or presidential statements in the first place. These may be transversally criticised for several reasons, namely, based on "no clear hierarchy and order (of such acts), significant restrictions by decree or administrative decision, reduced roles for parliaments and courts". In India, for instance, the Union government declared CoViD-19 a notified disaster under the Disaster Management Act, 2005 (DMA). It imposed a seemingly ill-conceived and ill-prepared nationwide lockdown in a matter of hours, which caused massive migration chaos (Chidambaram, 2020). Any citizen found violating the lockdown would be punished under the Indian Penal Code, 1860 [4]. With scant oversight, the DMA, along with the amended Epidemic Disease Act, 1897 (EDA), gave sweeping discretionary and over-riding powers to the executive; as their actions were done in "good faith" [5], the government appears mostly immune from the legal process. So, the combination of DMA and EDA, which are overly broad and vaguely worded, and susceptible to misuse can be weaponised to punish dissent.

Indeed, regimes of judicial exceptionalism certainly qualify the way fundamental rights can be enjoyed: publicly exercised rights may be curtailed in the name of health security. This ultimately opens debates on the absoluteness (or not) of particular rights. Such special regimes can be found in and permeate a multiplicity of legal orders. International human rights law permits derogations "in time of public emergency, which threatens the life of the nation" [6]. More specifically, derogations may be permitted if "required by exigencies of the situation" [7], hence establishing a wide marge d'appréciation. The neighbouring regime on economic, social and cultural (ESC) rights (International Covenant on Economic, Social and Cultural Rights) relates 
such derogations to a specific right stipulated in the instrument, namely, the right to form and join trade unions [8]. Approaching such a right rather broadly, similarities could arguably be found in relation to the right to public expression and protest, both constituting rights of collective nature (Jovanović, 2012; Buchanan, 1994) [9]. Conflicts with the right to health remain unaddressed; rather both sets of rights enjoy equal footing and require legislation to be adopted [10]. While international law seemingly treats such rights in a somewhat isolated manner, the ECHR identifies "the protection of health" as a distinct ground of exception [11], allowing for respective restrictions on the right to freedom of peaceful assembly and to freedom of association specifically [12]. In that sense, it arguably follows its civil/political rights tradition of the Convention, leaving little space for ESC rights to find full recognition. The Court, however, further engages with the "necessity" requirement that qualifies said restrictions, namely, considering such limits as orders of last resort to prevent the spreading of a disease (Zhang, 2020). A similar requirement is established by the Committee on Economic, Social and Cultural Rights. Exemptions from measures protecting the "interests of national security or public order" need to be interpreted in conjunction with those grounds "necessary in a democratic society" or "for the protection of the rights and freedoms of others" [13].

This may, in turn, raise questions on the essence of democratic values, materialising in the very right to participation in public life, including protest. The judiciary is hence, called upon to appreciate its significance under the extraordinary circumstances demanded for in the light of health protection.

\section{The silencing impact of executive orders I: constitutional courts as instruments of institutional control?}

In fact, progressive Constitutions gain meaning beyond the specific historical moment of their creation; they could be considered a purposive tool to create a democratic framework to strive for social change (Cachalia, 2018). To that end, Constitutions enjoin a facilitating duty on the Courts, contributing essentially to considering the former "living instruments" (Smith, 2009). Therefore, being the custodian of constitutional values and the final bulwark against the "majority's tyranny" (de Tocqueville, 1835) and the State's abuse of power, the Courts must rise to the occasion to uphold fundamental rights, democratic norms and constitutional enforcement mechanisms to ensure that constitutional rights are not trampled upon (Mzikamanda, 2020). In fact, constitutional safeguards prove key to place limits on possible abuse by emergency powers: as the Mexican context illustrates, respective judicial and legislative oversight may not be able to override by the executive branch (Grogan, 2020).

Disquietingly, in recent times, the Courts are often seen as reneging from checking executive powers whenever questions of fundamental rights and liberties are arbitrarily interfered with (TOM GINSBURG AND AZIZ Z. HUQ, 2019). In many states, rather than ensuring enjoyment of the rights and liberties guaranteed by the Constitution, they are found giving broad deference and the benefit of the doubt to governments (Vicente and Benítez, 2020). The resultant effect is what Lord Atkin described in Liversidge $v$ Anderson [14], namely, judges would become "more executive minded than the executive" and in that sense alienated from observing compliance with fundamental rights. Consequently, in many jurisdictions, checks and balances have shown to be in decline, exacerbated by the crisis surrounding the pandemic. In fact, the particular nature of emergency or presidential decrees may inhibit Courts from reviewing legislation on grounds of lacking competence as 
REPS

6,1

illustrated by the Czechian and Romanian contexts, respectively (Grogan, 2020). The very principle of legality demands discretionary powers to find detailed expression and to be judicially reviewed, respectively (Lazarus, 2020a). In some cases, the executive has demonstrably managed to limit access to justice by "freezing courts, limiting access to 'extremely urgent' or critical cases or giving sole access to violations of coronavirus measures" (Grogan, 2020). In that sense, emergency decrees may limit court action to cases of special emergency as becoming apparent in the case of Romania (Selejan-Gutan, 2020), Russia (Kalinichenko and Moskovkina, 2020) or Italy (Kypraios, 2020). Other limits lie in the very nature of decrees, which may not fulfil the requirements necessary for judicial review as illustrated by the situation in the Democratic Republic of Congo (Tazo, 2020). While the technicalities of decrees demonstrably limit the court's review functions, broader conclusions may be reached as to the balance of powers and checks and balances, which are transforming the State under Corona.

In the light of a dominant executive, little space is provided for counter narratives and (institutionalised) critique in the South African context, with the judiciary assuming an unclear position (Davis, 2020). Others have highlighted the court's position in considering governmental responses to the crisis unconstitutional (Friedman, 2020). Courts may also be absolved from review powers by Parliament as illustrated by the Romanian context as concerning the courts' competences in reviewing the relevant Presidential decree; this, in turn, would violate not only the principle of separation of powers but also the fundamental right to access to justice (Selejan-Gutan, 2020). The judiciary may also be circumvented in a different way: a growing accountability gap becomes apparent where heads of State informally encourage the police to shoot civilians as in the case of Donald Trump and Jair Bolsonaro (Scheppele, 2020). While far-reaching in scope, emergency powers should clearly not provide a carte blanche for taking unconstitutional action that is executive powers are not allowed to act with impunity under such orders (Grogan, 2020). At the same time, however, constitutional courts may become existential defence mechanisms of rule of law and adherence to fundamental rights. In the case of Brazil, for instance, the judiciary would disable authoritarian forms of legalism under Bolsonaro's autocratic rule that would jeopardise the role of mayors and subsidiary powers (Vieira, 2020).

As a matter of illustration, the Supreme Court of India (SCI) as a supposedly countervailing institution vis-à-vis the executive, appears to be reluctant to protect individuals' civil liberties (Dave, 2019; Sebastian, 2019; Kumar, 2017). By giving broad approval to executive measures on migrant workers during the State-wide lockdown including unreasonable and significant restrictions on the enjoyment of fundamental rights, the SCI has acted as a mere arm of the executive (Dave, 2020a, 2020b). In fact, strong implications for migrant workers have been observed elsewhere, paying tribute to the difficulties associated with shelters and food exacerbating what could be termed a humanitarian crisis (Atrey, 2020). Unsanitary and overcrowded conditions in housing facilities add to this as illustrated by the Singaporean context (Samtani, 2020). As a consequence, the Court has not been fulfilling its constitutional duty to scrutinise executive action contrary to developments at departmental court level including the High Court of Kerala, Karnataka, Orissa and Bombay: these had adopted suo moto measures and monitored the governments as granting food, housing and right to movement rights (Sebastian, 2020). Given the urgency of the situation, a suo moto intervention by the SCI was to be expected. In seemingly discharging its judicial functions, a Court that has 
declared itself as a qui vive to protect citizens' rights [15] and to have been on the forefront in safeguarding rights zealously, vigilantly and innovatively (Poddar and Nahar, 2017) is on a corrosion course (Shah, 2020) [16]. As the historical trend suggests, if that happens, reversals from the constitutional democratic free-fall would be enormously difficult and challenging (Ginsburg and Huq, 2019). Similar observations can be made in the case of the Venezuelan Constitutional Court, which absolved the Executive from its obligation to seek parliamentary approval for the declared state of alarm (Casal Hernández and Antoniazzi, 2020).

Understanding constitutional democracies in the classical sense of the term emerging as early as Ancient Greece, we will now concern ourselves with the rights underlying democratic architectures, which prove to be threatened by a somewhat absolute embracement of health security. That is both collective expression of dissent such as the right to assembly and protest and its further reaching implications for people*s' governance as a complementary instance of institutional control.

\section{The silencing impact of executive orders II: Examining the right to social protest and other forms of collective (public) expression}

The right to health may affect the enjoyment of other fundamental rights, including physical integrity, human dignity or indiscriminate treatment. Old established health acts may discard or not make mentioning of rights other than those relevant for maintaining health security. This is especially the case where such acts were established during military dictatorship such as in Latin America as the Paraguayan case illustrates: the health code is now used to restrict fundamental rights following a doctrine of ideological positivism (Trapani, 2020). A similar military legacy becomes apparent in the public space in other Latin American States adding to an increased presence of police forces (Gargarella, 2020), which suggests an enhanced implementation of a security paradigm to the detriment of fundamental rights. Excessive policing has been understood of one major shortcoming of the pandemic and the broad regulatory discretion exercised on the ground (Lazarus, 2020a).

We place a particular focus on the absolute nature of such rights and obligations, including respective derogations here. To further complicate matters, executive powers have been justified for motives beyond the protection of public health (Lazarus, 2020a). The rights at stake arguably demand special protection measures to be put in place for a few reasons. While the right to health as such is not granted special status in international human rights law, non-derogable or jus cogens status (Cassese, 2012) may be derived from the right to physical integrity. Exemptions are commonly reserved to international humanitarian law applying to armed conflict, highly disputable application of the death penalty such as in the case of the USA [17] or conservative debates around abortion. Secondly, said State emergency or other special sanitary regimes suggest high level risks for the (collective) survival of a State's population or alternatively, following a positivistic reading, demand particular measures to be put in effect following the informed judgement of governance mechanisms such as the executive. Conversely, it may be argued that such very mechanisms may seem somewhat ill-equipped or oriented to take due consideration of other fundamental rights at stake here. Civic control and democratic accountability instances may assume necessary review functions while translating collective dissent into the public domain and with it, the State's ambit (of responsibility). More particularly, this may manifest itself in forms of civic or 
REPS

6,1

participatory governance inherent to the right to protest, to assembly or other forms of collective expression.

Old-established categorical distinctions eventually come to the fore, taxonomising civil and political rights on the one hand and economic, social and cultural rights on the other hand, hence drawing categorical lines between different human rights generations (Vasak, 1977). This, however, renders the universal, indivisible, interdependent and interrelated nature of human rights (World Conference on Human Rights, 1993) null and void at worst or insignificant at best. The crisis has demonstrated high relevance for defending such interdependency and indivisibility, which are demanded by human dignity and the maintaining of democratic orders (Uprimny Yepes, 2020). A related component may be constitutive of the very bottomup, agency-oriented dimension human rights should strive for: rights holder communities should retain defining competence in the very construction of human rights (Young and Perelman, 2010). In the particular case at hand, the right to health might be perceived very differently by those (potentially) affected; similar multiplicities of impact may materialise as far as the right to movement, work, expression and participation are concerned. While the right to health as a social right seems predominantly at stake here, severe limitations on civil rights are noted as being curtailed, especially where emergency powers result in degrading democratic levels and the rule of law [18].

Indeed, the CoViD19 crisis has come with restrictions on civil liberties in particular, especially as far as public events, conglomerations of people in public and private spaces, gatherings, assemblies and ultimately public forms of collective dissent are concerned. In numerous States around the globe, this has resulted in absolute prohibitions, finding articulation in executive decrees and orders. It remains to be debated to what extent this proves exceptional given the nature of "emergency decrees" or could, alternatively, be understood as part of a gradual erosion of fundamental liberties since September 9/11 and in the light of missing institutional (constitutionalised) counterweight (Kempf, 2020). In fact, voicing concerns to governmental positions has been responded with criminal charges in Zimbabwe (Samtani, 2020).

Executive limits imposed on the enjoyment of the right to assembly and protest have, however, not remained un-responded. Most notably, the judiciary has demonstrably proven existential for circumventing such seemingly absolute divides. In a recent judgement, the German Constitutional Court ruled that prohibiting assemblies under a departmental regulation on CoViD-19 would infringe upon the discretionary scope qualifying the constitutionally recognised freedom to assembly [19] to be exercised here [20]. A second argument is related to the failure to consider the specific circumstances on a case-by-case basis [21]. Another essential procedural particularity lies with the very subject-matter motivating such public expression of dissent (CoViD19-related), which in itself required a speedy process, hence demanding a narrow interpretation of the specific circumstances at hand. This proves quintessential for legal recognition of the right to assembly in the specific CoViD-19 context and the predominance of a health security paradigm. By contrast, district and departmental courts had remained largely reluctant in pronouncing themselves on the arbitrariness of such exceptional regimes, including their detrimental impacts on other rights. A flexible treatment of the matter found accommodation, however, under a departmental CoViD-19 decree in the federal department of Hamburg, allowing for demonstrations in exceptional cases (Schipkowski, 2020). 
We might, however, ask to what extent courts would eventually grant exemptions where CoViD19 as a theme of the protest played merely marginal roles in terms of the claims for special treatment. In that sense, the infamous "case-by-case basis" in exercising discretion may very well demonstrate counter-democratic effects, that is, defining peoples' public concerns while judicially bolstering executive orders and (albeit arguably) governmental agendas. Critical remarks could, hence, be made as to the free exercise of public protest and freedom of assembly, rendering such right a mere window-dressing exercise of constitutional protection or a somewhat illusionary application of the separation of powers doctrine.

Following its philosophical origins, Montesquieu's France demonstrates a similar picture, a form of institutional malfunctioning of checks and balances in the current fifth Republic. Most notably, this becomes manifested in the case of the collective confinement in place since 23 March 2020 and respective penal sanctions for disrespecting its modalities. Accordingly, the government's self-rule has been criticised in the light of a virtually non-existing parliamentary control and a somewhat inactive Constitutional Court that approved the law adopted on the matter (Kempf, 2020). Similar criticism has been raised with regard to the Council of State's role in establishing a stricter approach towards limitations on individual liberties in the light of the governmental decree on health emergency (Platon, 2020; MeyerResende, 2020). Others have understood such decisions as part of broader developments steered towards a widening of the State's powers and a form of generalisation (and normalisation) of new practices operationalised by those implementing the law (Tréguer, 2020). This, in turn, necessarily jeopardises the broad enjoyment of individual liberties, let alone collective articulations of such rights and thereby essentially prevents people from participating publicly, that is, as a possible Rousseauian fourth instance of control of the State's powers.

Similar questions were in fact addressed by the Superior Tribunal of Justice of Aragón, one of Spain's autonomous communities (departments), annulling a departmental resolution regulating CoViD19 matters that prohibited the right to assembly [22]. It essentially takes account of the low intensity of the "state of alert", especially as relating to the impact of the respective special judicial regime on the enjoyment of such right, the right to demonstrate. Interestingly, the tribunal takes a reconcilable turn here: by interpreting the State-wide royal decree on CoViD19, the Court does not identify any violation of the safety measures on the right to protest, but rather the related(?) individual freedom of movement. By tracing its origins back to the underlying freedom of expression, the Court explicitly distinguishes between the right to assembly and to demonstrate on the one hand and (participation in) other social, collective or public events on the other. In line with existing jurisprudence developed by the European Court of Human Rights [23], the Court establishes an intrinsic relationship between freedom of expression and the right to demonstrate, as well as its overarching implications on the free exposure of ideas, defence of interests at stake while disclosing problems and implications in a public space.

Indeed, a restrictive or literal reading of the limits imposed on the freedom of movement in times of Corona may invite conflicts of rights to arise or be constructed in the first place. This comes with yet another interpretative challenge, that of appreciating spatial distance between people as demanded by health experts while allowing for collective public expression (of dissent), representing at the same time a rarely embraced policy amongst affected States. At worst, an absolute understanding 
REPS

6,1

of the right to health may be reflected in decrees that explicitly illegalise freedom of association and protest.

\section{The discriminate impact of executive orders: uncovering vulnerabilities,} social inequalities and other social ills in the light of invisibilising measures

CoViD19-related regulations demonstrably impose restrictions on the enjoyment of fundamental rights other than the right to health, physical (and mental) integrity, well-being and public safety. We will concern ourselves with a double binding effect or burden here, catalysed or reinforced by the enactment of such - whilst temporary regulatory orders, namely, discriminate effects of CoViD19 policies and collective forms of expression including protests that relate to and articulate such effects.

While not discriminatory as such, detrimental impacts may be felt quite vividly, amounting to indirect forms of discrimination (Clapham, 2015) and constitute a distinct form of vulnerability. It may be further argued that the nature of executive measures being adopted at high speed and by a few public officers potentially excludes the demands and critique articulated by the disadvantaged (Gargarella, 2020). Disproportionate impacts as enhanced by the virus may be manifold and include inequalities as relating to economic impacts on particular sectors such as care work and become manifested in gender-based violence, as well as impacts on households including education-related effects on children in the UK (Reeves, 2020). As demanded by OHCHR, CoViD-19 measures are supposed to be proportionate, as well as necessary and applied non-discriminatorily (Lazarus, 2020a, 2020b; United Nations Office of the High Commissioner for Human Rights, 2020); hence, establishing criteria, which further define such discriminate impact. The private sphere certainly bears certain dangers in that regard by isolating victims from society, exposing them to their abusers while disabling access to support systems (Goudsmit, 2020). Relatedly, inequalities during CoViD-19 have been understood as reinforcing stereotyping and violence, voicelessness and exclusion while finding their roots in underlying structures (Fredman, 2020). It may be further noted that assessment results on the impact of equality measures included in a UK CoViD-19 regulation would not be disclosed by the government (Gargarella, 2020), hence implying complementary breaches. Reasons for pre-existing inequalities to be accentuated in times of the pandemic are manifold: preventive measures might not be easily taken due to crowded housing, pre-existing pathologies could place them at higher risk and social impacts including reduced income may become real (Uprimny Yepes, 2020).

CoViD-19 has also brought about new inequalities, this may concern low-income workers temporally employed in seasonal harvesting and the meat industry, for instance, who do not benefit equally from the new health regime (Zingher, 2020; Maurin, 2020): EU citizens from recently acceded States are exposed to inhuman working and housing conditions elsewhere in the Union, hence facilitating the spread of the virus amongst dedicated groups. Indeed, harmonisation of EU social protection on the matter remains scarce (De Witte and Dawson, 2012) [24]. At a broader scale, inadequate housing conditions including social-economic marginalisation have been described as decisive for exposing people disproportionately to the virus in Sweden and France, being indicative of discriminate regulatory effects. Socio-economic rights have undergone major limitations during CoViD-19, especially where economic compensation structures prove to be inadequate (Lazarus, 2020a).

Particularly, damaging effects may be noted in relation to dedicated groups. Roma communities, for instance, have undergone discrimination as the main targets of lockdown practice including military intervention in the Slovakian context 
(Henčeková and Drugda, 2020). Confinement lends itself for particularly discriminatory treatment indeed; refugees and their particular housing obligations(!) deserve particular mentioning here. These find their roots in the regimes governing specific asylum facilities, so-called "Anker institutions" in Germany, referring to "arrival, communal distribution, decision and return". Where CoViD-19 infections were detected, collective confinement was imposed in Bavaria and other departments, hence jeopardising people's sheer survival, safe living and ultimately dignified living conditions (Riese et al., 2020). A recent departmental court decision, however, granted exemption from a Saxonian CoViD-19 regulation (infection protection law) that had demonstrated legal loopholes and discriminate effects on refugees [25]. To ensure health prevention said housing obligations were to be annulled, thereby paying due regard to asylum seekers and their very interests in the light of the particular discretion to be exercised here.

Such debates may, however, be superseded by an ever-increasing need for panregional solutions, especially considering the intensity of the crisis (e.g. Greece/EUTurkey border conflict) (Enria and Gerwens, 2020). In that sense, departments have been envisaging options to sue the federal government for jeopardising "departmental reception programmes" that would allow for refugee protection throughout and beyond the CoViD-19 crisis as demanded by prominent nongovernmental organisations (Memarnia, 2020). Again, executive measures on the matter need to be understood against the background of inter-institutional dynamics, the executive and judiciary in particular. Isolated domestic responses have proven to be counter-productive amounting to, for instance, increased prices for sanitary resources (Uprimny Yepes, 2020). International cooperation constitutes a crucial obligation of its own accord, requiring sharing of results of medical research, cooperation to address economic impacts in low-income States including extraterritorial obligations (Maastricht Principles) and scientific cooperation. In the case of European policies, limits are set by the very sectorial structure of decision-making, leaving refugee-related matters to be regulated by intergovernmental powers. Other related shortcomings might be found in economic sovereignty doctrines, which becomes apparent in the production of masks, medicine or the control of human movement; migrants being particularly subjected to such policies (Dignat, 2020). This, in turn, demands shared competences exercised domestically and supranationally, building on non-State actors who have been integrated into a global community that is supposed to facilitate the circulation of technologies, ideas and financing (Uprimny Yepes, 2020).

In the meanwhile, civil society campaigns resisting conservative migration policies are placed on hold or confront arbitrary enforcement practice, constituting a perpetuating effect on its own. Indeed, the shrinking public space does not allow on-the-ground violations to become visualised, let alone group rights to become articulated. Following the rationale of a virtually absent State (monitoring) in the private sphere such as in the case of gendered forms of violence [26], refugees find themselves particularly exposed to the arbitrariness of housing regulations. Lacking opportunities to express their disapproval on CoViD-19 regulations add to this. Collective protest as relating to health emergency cases in refugee housing facilities, for instance, has been vehemently suppressed by administrative authorities (Zuschlag, 2020). The right to collective public expression, however, needs to be understood as a means for legal mobilisation, as a way to uncover rights violations, as means of executive control and eventually - albeit relatedly - as an ultimate, inclusive form of people's governance. 
REPS

6,1

\section{Concluding remarks: towards a paradigm shift in health governance, institutional control and fundamental rights?}

History is replete with instances that pandemics, epidemics, disasters, other similar public crises have challenged and reshaped the stranglehold of the power levers in favour of autocratic regimes (Taylor, 2020). Most of the States tilted towards highhanded and unconstitutional approaches were confronted with enormously difficult choices to effectively respond to the spread of the pandemic and maintain fundamental rights and freedoms (Daragahi, 2020). Are stringent, extreme and extraordinary measures the only course of action to address public health risks?

Much of the current crisis lies indeed in the challenges around tailored governance responses including collateral damage for the diverse landscape of human rights. As the findings suggest, the State as a traditionally viewed "black box" (Waltz, 1979) needs to be unpuzzled in view of its complex intra-institutional architecture. This may prove fatal for protecting fundamental rights given that international law deals with human rights protection in a somewhat dichotomic manner, most notably by establishing relations between the State as a duty bearer and the people*s as rights holders (Tomuschat, 2015). While constitutional designs provide a clearer picture of responsibilities including instances of review, these fall short of working according to their originally envisaged functions in times of Corona. In many ways then, fundamental rights are subjected to a gradual formalisation and institutionalisation of arbitrariness. In fact, we are testifying of what could be termed inter-institutional malaise perpetuated by the nature of emergency orders. This may be attributed to newly, unchecked forms of expert governance, failing accountabilities and checks and balances, lacking review functions and an untransparent fragmentation of responsibilities to those subjected to its jurisdictional orbits. The judiciary appears particularly vulnerable in that regard, being absolved from its traditional interpretative authority as to fundamental rights and being deprived of its quintessential function as a constitutional guardian. Implications are manifold, including the suspension of rights that could substantially bolster review functions and ultimately dissent.

The right to protest, assembly and other forms of collective public expression could eventually serve as a fourth instance, exercising control over current forms of governance. Balancing such rights in view of public safety, "national" interest or security becomes ever more decisive. The former are dealt with more delicately by the judiciary, which demonstrably considers the application of such rights on a case-bycase basis while departing from constitutionally recognised fundamental rights in the first place rather than treating rights as a concern amongst many. In that sense, people*s' publicly expressed dissent adds to instances of institutional control as developed by the judiciary, hence counterbalancing the ever-growing powers selfattributed by the executive.

We may similarly wonder what kind of repercussions could have been motivated by the current crisis in view of the governmental regimes in place. The pandemic may have in fact exacerbated the sharp decline and rapid erosions of representative forms of democracy or exposed fault lines of its institutions, yet the pandemic as such cannot be blamed for democratic backsliding. Instead, there are abundant indications that in liberal democratic forms of governance, the steep rise of authoritarianism is taking place over a considerable period of time (Waldner and Lust, 2018; Kuo, 2019; Brubaker, 2017). The rise of populist leaders, conservative governments and political parties in inter-alia the US, Brazil, UK, India, Hungary, Italy, Germany, France, The 
Netherlands, Spain and Poland have been gradually eroding the rule of law and democratic safeguards (Bieber, 2020).

The global trend suggests that democratic decline mainly operates either through attacks on civil rights, stripping minorities, refugees, migrants of their rights or illegitimate control of independent and autonomous institutions (Takis, 2019). The repressive emergency measures adopted by the States to contain the pandemic may be the most audacious assault on constitutionalism either based on "limited government" or the (supposed) welfare of the people (Barber, 2018). Hence, it may be contended that current

Executive powers in times of corona forms of governance are woefully inadequate to protect and preserve constitutional rights (Robson, 2020). Therefore, States must move from negative to positive constitutionalism (Berlin, 1958), that is to embrace "freedom to", instead of "freedom from" doctrines to hold governments accountable for providing welfare policies while granting the right to express dissent publicly, especially where CoViD-19 regulations demand or imply non-derogable restrictions.

\section{Notes}

1. Further debates in the next section/chapter.

2. Korematsu v US 323 US 214 (1944).

3. Kuldip Nayar v Union of India AIR 2006 SC 3127.

4. Section 188 is related to the disobedience to order duly promulgated by public servant.

5. Section 73 of the DMA, 2005.

6. Article 4(1), International Covenant on Civil and Political Rights.

7. Id.

8. Article 8(1), International Covenant on Economic, Social and Cultural Rights.

9. See following work for further debates Jovanović (2012), Buchanan (1994).

10. CESCR, 1990, General Comment 3, The Nature of States Parties' Obligations (Art. 2, Para. 1, of the Covenant).

11. Article 11(2), European Convention on Human Rights.

12. Article 11(1), European Convention on Human Rights.

13. Article 8(1)(c), International Covenant on Economic, Social and Cultural Rights.

14. Liversidge $v$ Anderson [1941] UKHL 1.

15. State of Madras v VG Row 1952 AIR 196.

16. Prem Chand Garg v Excise Commissioner, MANU/SC/0082/1962.

17. See, International Covenant on Civil and Political Rights, Optional Protocol I.

18. Id.

19. Article 8(1) German Basic Law.

20. Judgement 1 BvR 828/20, para.13; see also judgement 1 BvQ 37/20.

State of Madras v VG Row 1952 AIR 196.

21. Id. para.14. 


\section{REPS \\ 6,1}

22. Judgement $000151 / 2020$.

23. See, Case of Stankov and The United Macedonian Organisation Ilinden v Bulgaria Applications nos. 29221/95 and 29225/95, 2001, Rekvényi v Hungary Application no. 25390/94, 1999.

24. See also, International Transport Workers' Federation and Finnish Seamen's Union v Viking Line ABP and OÜ Viking Line Eesti, CJEU - C 438/05/; Laval v Svenska Byggnadsarbetareförbundet, Case C-341/05; Dirk Rüffert v Land Niedersachsen, Case C-346/ 06 cases for cautious jurisprudential approaches, respectively; first harmonising obligations arising with Directive 96/71/EC).

25. Decision VG-LE-3-L-204_20.A.

26. CEDAW, General Recommendation No. 19, Violence against Women (1992); CEDAW, General Recommendation No. 14, Female Circumcision (1990); CEDAW, General Recommendation No. 12 , Violence against Women (1989).

\section{References}

Alon, T., Doepke, M., Olmstead-Rumsey, J. and Tertilt, M. (2020), "The impact of covid-19 on gender equality", CRC TR 224 Discussion Paper Series crctr224_2020_163, University of Bonn and University of Mannheim.

Atrey, S. (2020), "Human rights implications of covid-19: a comparative perspective", Oxford Law Webinar on The COVID-19 Crisis: Legal, Policy and Ethical Challenges

Barber, N.W. (2018), The Principles of Constitutionalism, Oxford Scholarship Online.

Bates, E.S. (2020), “COVID-19 symposium: Article 2 ECHR's positive obligations - how can human rights law inform the protection of health care personnel and vulnerable patients in the COVID19 pandemic", OpinioJuris April 1, 2020, available at: http://opiniojuris.org/2020/04/01/covid-19symposium-article-2-echrs-positive-obligations-how-can-human-rights-law-inform-the-protectionof-health-care-personnel-and-vulnerable-patients-in-the-covid-19-pandemic/

Berlin, I. (1958), Two Concepts of Liberty, Clarendon Press.

Bieber, F. (2020), The Rise of Authoritarianism in the Western Balkans, Palgrave Macmillion.

Bourdelais, P. (2014), "Le retour des dispositifs de protection anciens dans la gestion politique des épidémies”, Extrême-Orient, Extrême-Occident, Vol. 37 No. 37, available at: http://journals. openedition.org/extremeorient/345

Brubaker, R. (2017), "Why populism?”, Theory and Society, Vol. 46 No. 5.

Buchanan, A. (1994), "liberalism and group rights", in Jules, L. (Ed.), Harm's Way: Essays in Honor of Joel Feinberg, Cambridge Studies in Philosophy and Law, Coleman and Buchanan.

Bulmer, E. (2017), "Federalism", International IDEA Constitution-Building Primer 12 available at: http://constitutionnet.org/sites/default/files/2017-10/federalism-primer.pdf (accessed June 6, 2020).

Cachalia, F. (2018), "Democratic constitutionalism in the time of the postcolony: beyond triumph and betrayal", South African Journal on Human Rights, Vol. 34 No. 3.

Cassese, A. (2012), Realizing Utopia: The Future of International Law, Oxford Scholarship Online.

Casal Hernández, J.M. and Antoniazzi, M.M. (2020), "States of emergency without rule of law: the case of Venezuela", VerfBlog, available at: verfassungsblog.de/states-of-emergency-without-rule-oflaw-the-case-of-venezuela/

Center for Civil and Political Rights (2020), States of Emergencies in Response to the Covid-19 Pandemic, Center for Civil and Political Rights, available at: https:/datastudio.google.com/reporting/ 1sHT8quopdfavCvSDk7t-zvqKIS0Ljiu0/page/dHMKB (accessed June 6, 2020). 
Chidambaram, P. (2020), Unpreparedness Has Been the Hallmark of Modi Government since the First Covid-19 Case, The Indian Express, available at: indianexpress.com/article/opinion/columns/ coronavirus-lockdown-india-covid-19-p-chidambaram-6336437/ (accessed June 6, 2020).

Christian, T. (2015), Human Rights: Between Idealism and Realism, Oxford University Press.

\section{Executive powers in times of corona}

Clapham, A. (2015), Human Rights: A Very Short Introduction, Oxford University Press.

Daly, T.G. (2020), "Democracy and the global emergency - shared experiences, starkly uneven impacts", VerfBlog, available at: verfassungsblog.de/democracy-and-the-global-emergencyshared-experiences-starkly-uneven-impacts/ (accessed June 6, 2020).

Daragahi, B. (2020), "Coronavirus could be used by authoritarian leaders as excuse to undermine democracy, experts warn", Independent, available at: www.independent.co.uk/news/health/ coronavirus-us-cases-government-pandemic-democracy-covid-19-a9407011.html (accessed June 6, 2020).

Dave, D. (2019), "Supreme court has not acted with urgency to protect citizens from executive excesses", The Indian Express, available at: indianexpress.com/article/opinion/columns/caa-citizenshipamendment-act-supreme-court-constitution-of-india-6181772/ (accessed June 6, 2020)

Dave, D. (2020a), Missing Parliament and the Judiciary in the Covid Crisis, The Indian Express, available at: indianexpress.com/article/opinion/columns/india-coronavirus-parliament-judiciarylockdown-6367368/ (accessed June 06, 2020).

Dave, D. (2020b), SC Order on Migrant Labour is Premised on Unchallenged Claims of Govt, It Curtails Press Freedom, The Indian Express, available at: indianexpress.com/article/opinion/columns/ supreme-court-migrants-coronavirus-india-6344647/ (accessed June 06, 2020).

Davis, D. (2020), "Roundtable session, the authoritarian resurgence: autocratic legalism in comparative perspective", Law and Society Association 2020 Annual Meeting.

de Tocqueville, A. (1835), de la democratie en Amerique, Gallimard

De Witte and Dawson (2012), "The EU legal framework of social inclusion and social protection: between the Lisbon strategy and the Lisbon treaty", in Cantillon, B. and Ploscar, P. (Eds), Social Inclusion and Social Protection in the EU: Interactions between Law and Policy, De Witte and Dawson

Diallo, K. (2020), "Viter au heurt de la COVID-19 en afrique de l'Ouest: à qui profite la crise?", Wathi, available at: www.wathi.org/voter-a-lheurt-de-la-covid-19-en-afrique-de-louest-a-qui-profite-lacrise/

Dignat, E. (2020), "Covid-19: la responsabilité globale des états", Centre de Recherches Internationales, Sciences Po

Enria, N. and Gerwens, S. (2020), "Greek-Turkish border crisis: refugees are paying the price for the EU's failure to reform its asylum system”, LSE Blog, available at: blogs.lse.ac.uk/greeceatlse/ 2020/04/08/greek-turkish-border-crisis-refugees-are-paying-the-price-for-the-eus-failure-toreform-its-asylum-system/ (accessed May 15, 2020).

Ferrante, L. and Fearnside, P.M. (2020), "Protect indigenous peoples from COVID-19", Science, Vol. 368 No. 6488 , p. 6488.

Fredman, S. (2020), "Palliation or protection: how should the equality act inform the government's response to covid-19?", Oxford Law Webinar on The COVID-19 Crisis: Legal, Policy and Ethical Challenges

Friedman, N. (2020), "Human rights implications of covid-19: a comparative perspective", Oxford Law Webinar on The COVID-19 Crisis: Legal, Policy and Ethical Challenges

Gargarella, R. (2020), "The fight against COVID-19 in Argentina: executive vs legislative branch", VerfBlog, available at: verfassungsblog.de/the-fight-against-covid-19-in-argentina-executive-vslegislative-branch/ 


\section{REPS \\ 6,1}

Gaspard, P. (2020), "Viral authoritarianism: testing the limits of democracy", Reporting Democracy, available at: balkaninsight.com/2020/04/16/viral-authoritarianism-testing-the-limits-of-democracy/ (accessed June 6, 2020).

Gebrekidan, S. (2020), "For autocrats, and others, coronavirus is a chance to grab even more power", The New York Times, available at: www.nytimes.com/2020/03/30/world/europe/coronavirusgovernments-power.html (accessed June 6, 2020).

Ginsburg, T.O.M. and Huq, A.Z. (2019), How to save a Constitutional Democracy, University of Chicago Press.

Goudsmit, M. (2020), "Comment on regulatory strategies and conceptions of health", Oxford Law Webinar on The COVID-19 Crisis: Legal, Policy and Ethical Challenges

Greene, A. (2020), "States should declare a state of emergency using article 15 ECHR to confront the Coronavirus pandemic", Strasbourg Observers, available at: strasbourgobservers.com/2020/04/01/ states-should-declare-a-state-of-emergency-using-article-15-echr-to-confront-the-coronavirus-pandemic/

Grogan, J. (2020), "States of emergency", VerfBlog, available at: verfassungsblog.de/states-ofemergency/ (accessed June 6, 2020).

Guterres, A. (2020), "SG calls on strengthening immunity against "virus of hate", OHCHR, available at: www.ohchr.org/en/NewsEvents/Pages/StoriesbyDate.aspx

Halmai, G., Mészáros, G. and Scheppele, K.L. (2020), "From emergency to disaster: how Hungary's second pandemic emergency will further destroy the rule of law", VerfBlog, available at: verfassungsblog.de/from-emergency-to-disaster/ (accessed June 6, 2020).

Henčeková, S. and Drugda, Š. (2020), "Slovakia: change of government under COVID-19 emergency", VerfBlog, available at: verfassungsblog.de/slovakia-change-of-government-under-covid-19emergency/

Hobbes, T. (1651), Leviathan: The First Part, of Man, Andrew Crooke, London

HRW (2020), Covid-19 Fueling anti-Asian Racism and Xenophobia Worldwide, HRW, available at: www.hrw.org/news/2020/05/12/covid-19-fueling-anti-asian-racism-and-xenophobia-worldwide (accessed June 6, 2020).

Jovanović, M.A. (2012), Collective Rights: A Legal Theory, Cambridge University Press

Kalinichenko, P. and Moskovkina, E. (2020), "Russia - with scepter and corona”, VerfBlog, available at: verfassungsblog.de/russia-with-scepter-and-corona/

Kempf, R. (2020), "Et le gouvernement décida de confiner les libertés", Le Monde Diplomatique, available at: www.monde-diplomatique.fr/2020/05/KEMPF/61747 (accessed June 06, 2020).

Kumar, A.P. (2017), “Are people losing faith in the courts?”, $52 \mathrm{EPW} \mathrm{16,} \mathrm{available} \mathrm{at:} \mathrm{www.epw.in/}$ journal/2017/16/law-and-society/are-people-losing-faith-inthe-courts.html

Kuo, M.-S. (2019), "Against instantaneous democracy”, International Journal of Constitutional Law, Vol. 17 No. 2.

Kypraios, C. (2020), "Human rights implications of covid-19: a comparative perspective", Oxford Law Webinar on The COVID-19 Crisis: Legal, Policy and Ethical Challenges

Lange, B. (2020), “Regulatory 'strategy' for covid-19?”, Oxford Law Webinar on The COVID-19 Crisis: Legal, Policy and Ethical Challenges.

Lazarus, L. (2020a), "Human rights implications of Covid-19: a comparative perspective", Oxford Law Webinar on The COVID-19 Crisis: Legal, Policy and Ethical Challenges.

Lazarus, L. (2020b), "Introduction, in a preliminary human rights assessment of legislative and regulatory responses to the COVID-19 pandemic across 11 jurisdictions", Bonavero Report No. 3/2020, Bonavero Institute of Human Rights at University of Oxford.

Locke, J. (1689), Two Treatises of Government, Hacket publishing company Inc.

McKell, P. (2020), Federalism \& the COVID-19 Pandemic - A Compendium of (Re)Sources, available at: www.mcgill.ca/federalism/federalism-covid-19-pandemic 
Montesquieu, C.L.d.S.B. (1892), Esprit Des Lois, Libraire Ch. Delagrave.

Maurin, J. (2020), “Covid-19 in der fleischindustrie: Kein fleisch - keine ausbeutung”, taz, available at: taz.de/Covid-19-in-der-Fleischindustrie/!5681708/

Memarnia, S. (2020), “Corona in flüchtlingsunterkünften: 'die leute haben angst”, taz, available at: taz. de/Corona-in-Fluechtlingsunterkuenften/:5684568/(accessed May 20, 2020).

Memish, Z.A., Ahmed, Q.A., Schlagenhauf, P., Doumbia, S. and Khan, A. (2020), "No time for dilemma: mass gatherings must be suspended", The Lancet, Vol. 395 No. 10231, available at: www. thelancet.com/journals/lancet/article/PIIS0140-6736(20)30754-6/fulltext (accessed June 6, 2020).

Meyer-Resende, M. (2020), “The rule of law stress test: EU member states' responses to COVID-19”, VerfBlog, available at: verfassungsblog.de/the-rule-of-law-stress-test-eu-member-states-responses-to-covid-19/

Meyer-Resende, M. (2020), “The rule of law stress test: EU member states' responses to COVID-19", VerfBlog (May 24, available at: verfassungsblog.de/the-rule-of-law-stress-test-eu-member-statesresponses-to-covid-19/

Mzikamanda, R.R. "Constitutionalism and the judiciary: a perspective from Southern Africa", available at: www.justice.gov.za/alraesa/conferences/2011malawi/constitutionalism-and-the-judiciary_mzikamanda. pdf (accessed June 6, 2020).

Platon, S. (2020), "From one state of emergency to another - emergency powers in France", VerfBlog, available at: verfassungsblog.de/from-one-state-of-emergency-to-another-emergency-powers-infrance/

Poddar, M. and Nahar, B. (2017), "Continuing Mandamus - a judicial innovation to bridge the rightremedy gap”, 10 NUJS L. Rev. 555

Pufendorf, S. (1672), "le droit de la nature et des gens, jean barbeyrac", (trans.) (Caen, Centre de Philosophie Politique et Juridique de l'Université de Caen; reprint of Basel, Thourneisen, 1732)

Quraishi, S.Y. (2020), "Across the world, the coronavirus pandemic has become an invitation to autocracy", The Wire, available at: thewire.in/government/coronavirus-pandemic-autocracy (accessed June 6, 2020).

Reeves, A. (2020), "Palliation or protection: how should the equality act inform the government's response to covid-19?", Oxford Law Webinar on The COVID-19 Crisis: Legal, Policy and Ethical Challenges,

Riese, D., Jakob, C., Baur, D., Litschko, K. and Ellersiek, H. (2020), "Schutz vor corona für geflüchtete: Zu sechst ein zimmer, keine seife", taz, available at: taz.de/Schutz-vor-Corona-fuer-Gefluechtete/!5673786/

Robson, R. (2020), "Positive constitutionalism in a pandemic: demanding responsibility from the trump administration”, ConLawNOW, Vol.12, p. 15.

Roth, K. (2020), "How authoritarians are exploiting the Covid-19 crisis to grab power", The New York Review of Books, available at: www.nybooks.com/daily/2020/03/31/how-authoritarians-areexploiting-the-covid-19-crisis-to-grab-power/ (accessed June 6, 2020).

Ryan, F. (2020), "Coronavirus hits ill and disabled people hardest, so why is society writing us off?", The Guardian, available at: www.theguardian.com/commentisfree/2020/apr/29/coronavirusdisabled-people-inequality-pandemic (accessed June 6, 2020).

Samtani, S. (2020), "Human rights implications of Covid-19: a comparative perspective", Oxford Law Webinar on The COVID-19 Crisis: Legal, Policy and Ethical Challenges,

Scheinin, M. (2020), “COVID-19 symposium: to derogate or not to derogate?”, OpinioJuris, available at: http://opiniojuris.org/2020/04/06/covid-19-symposium-to-derogate-or-not-to-derogate/

Scheppele, K.L. (2020), "Roundtable session, the authoritarian resurgence: autocratic legalism in comparative perspective", Law and Society Association 2020 Annual Meeting.

Schipkowski, K. (2020), "Versammlungsfreiheit in Hamburg: Demonstrieren im einzelfall okay", taz, available at: taz.de/Versammlungsfreiheit-in-Hamburg/!5674816/

Sebastian, M. (2019), "How has the supreme court fared during the modi years?", The Wire, available at: thewire.in/law/supreme-court-modi-years 


\section{REPS \\ 6,1}

Sebastian, M. (2020), "Migrant workers cases: SC failed to rise to the occasion", Livelaw, available at: www.livelaw.in/columns/migrant-workers-cases-sc-failed-to-rise-to-the-occasion-156541 (accessed June 6, 2020).

Selejan-Gutan, B. (2020), "Romania in the Covid era: between corona crisis and constitutional crisis", VerfBlog, available at: verfassungsblog.de/romania-in-the-covid-era-between-corona-crisis-andconstitutional-crisis/

Serhan, Y. (2020), "The EU watches as Hungary kills democracy", The Atlantic, available at: www. theatlantic.com/international/archive/2020/04/europe-hungary-viktor-orban-coronavirus-covid19democracy/609313/ (accessed June 6, 2020).

Shah, A.P. (2020), "The lockdown is a dangerous experiment, India's democracy will not emerge unscathed", The Wire, available at: thewire.in/law/lockdown-democracy-rights-india-supremecourt (accessed June 06, 2020).

Smith, S.D. (2009), "What does constitutional interpretation interpret?", in Grant, H. (Ed.), Expounding the Constitution: Essays in Constitutional Theory, Cambridge University Press.

Takis, S.P. (2019), Populism and Liberal Democracy: A Comparative and Theoretical Analysis, Oxford University Press.

Taylor, C. (2020), "1918 Flu pandemic boosted support for the Nazis, fed study claims”, CNBC, available at: www.cnbc.com/2020/05/06/1918-flu-pandemic-boosted-support-for-the-nazis-fed-study-claims.html (accessed June 7, 2020).

Tazo, É.A.G. (2020), “Cameroon's fight against COVID-19: an ordinary legal framework for an extraordinary situation", VerfBlog, available at: verfassungsblog.de/cameroons-fight-againstcovid-19-an-ordinary-legal-framework-for-an-extraordinary-situation/

The Lancet (2020), “COVID-19: protecting health-care workers”, 395, 10.1016/S0140-6736(20)30644-9 (accessed June 6, 2020).

Theil, S. (2020), "Human rights implications of covid-19: a comparative perspective", Oxford Law Webinar on The COVID-19 Crisis: Legal, Policy and Ethical Challenges

Tidball, M. (2020), Too Often Forgotten: How Do we Create a Country That Values Disabled People and Closes the Inequality Gap we Face?, Oxford Law Webinar on The COVID-19 Crisis: Legal, Policy and Ethical Challenges.

Tomuschat, C. (2015), Human Rights: Between Idealism and Realism, Oxford University Press.

Trapani, C.C. (2020), "COVID-19 in Paraguay: health success and constitutional deficit", VerfBlog, available at: verfassungsblog.de/covid-19-in-paraguay-health-success-and-constitutional-deficit/ (accessed June 06, 2020).

Tréguer, F. (2020), "The state and digital surveillance in times of the covid-19 pandemic", available at: www.sciencespo.fr/ceri/en/content/state-and-digital-surveillance-times-covid-19-pandemic (accessed June 6, 2020).

United Nations Office of the High Commissioner for Human Rights (2020), "Covid 19 guidance", available at: www.ohchr.org/EN/NewsEvents/Pages/COVID19Guidance.aspx

Uprimny Yepes, R. (2020), “15 Recomendaciones del comité DESC de la ONU frente al coronavirus”, available at: www.gi-escr.org/blog/15-recommendations-from-the-un-cescr-to-address-the-coronavirus

Vaitheeswaran, K. and Datar, A.P. (2015), “GST’s seven deadly defects”, The Indian Express, available at: indianexpress.com/article/opinion/columns/gsts-seven-deadly-defects/ (accessed June 6, 2020).

Vasak, K. (1977), "Human rights: a thirty-year struggle: the sustained efforts to give force of law to the universal declaration of human rights", 30 UNESCO Courier 11

Vicente, F. and Benitez, R. (2020), "Hercules leaves (but does not abandon) the forum of principle: courts, judicial review, and COVID-19", Int'l J. Const. L. Blog, www.iconnectblog.com/herculesleaves-but-does-not-abandon-the-forum-of-principle-courts-judicial-review-and-covid-19/. 
Vieira, O. (2020), "Roundtable session, the authoritarian resurgence: autocratic legalism in comparative perspective", Law and Society Association 2020 Annual Meeting.

World Conference on Human Rights (1993), "Vienna declaration and programme of action", World Conference on Human Rights, A/CONF.157/23

Vile, M.J.C. (1967), "constitutionalism and the separation of powers".

Waldner, D. and Lust, E. (2018), "Unwelcome change: coming to terms with democratic backsliding", Annual Review of Political Science, Vol. 21 No. 1.

Waltz, K. (1979), Theory of International Politics, Random House.

Wang, H., Li, T., Barbarino, P., Gauthier, S., Brodaty, H., Molinuevo, J.L., Xie, H., Sun, Y., Yu, E., Tang, Y., Weidner, W. and Yu, X. (2020), "Dementia care during COVID-19", The Lancet, Vol. 395 No. 10231, doi: 10.1016/S0140-6736(20)30755-8. (accessed June 6, 2020).

Wenham, C., Smith, J., Morgan, R. and "on behalf of the Gender and COVID19 Working Group” (2020), "COVID-19: the gendered impacts of the outbreak", The Lancet, Vol. 395 No. 10227, doi: 10.1016/ S0140-6736(20)30526-2 (accessed June 6, 2020).

Young, C. and Perelman, J. (2010), "Rights as footprints: a new metaphor for contemporary human rights practice", 9 Nw. J. Int.L Hum. Rts. 27

Zhang, Y. (2020), "Reexamination of human rights derogation in combating coronavirus", Paper Session on The Boundaries of Hegemonic Human Rights, Law and Society Association 2020 Annual Meeting

Zingher, E. (2020), “Ausbeutung in Corona-Krise: Spargel unser”, taz, available at: taz.de/Ausbeutungin-Corona-Krise/!5676706/

Zuschlag, A. (2020), "Geflüchtete in der coronakrise: Flehen um den notarzt", taz, available at: taz.de/ Gefluechtete-in-der-Coronakrise/!5677017/ (accessed June 06, 2020).

\section{Corresponding author}

Jessika Eichler can be contacted at: jessika.eichler@gmail.com

For instructions on how to order reprints of this article, please visit our website: 